\title{
Cembranolides from the Leaves of Croton gratissimus
}

Moses K. Langat, ${ }^{\dagger, \S}$ Neil R. Crouch, ${ }^{\S, \neq}$ Peter J. Smith ${ }^{\perp}$ and Dulcie A. Mulholland ${ }^{* \dagger, \S}$

${ }^{\dagger}$ Division of Chemical Sciences, Faculty of Health and Medical Sciences, University of Surrey, Guildford, GU2 7XH, Surrey, UK.

${ }^{\S}$ School of Chemistry, University of KwaZulu-Natal, Durban, 4041, South Africa

¥ Ethnobotany Unit, South African National Biodiversity Institute, PO Box 52099, Berea Road 4007, Durban, South Africa

${ }^{\perp}$ Department of Medicine, Division of Clinical Pharmacology, University of Cape Town, K45

Old Main Building, Groote Schuur Hospital, Observatory, 7925, Cape Town, South Africa

\section{Corresponding author}

*Tel: +44 1483 686827. Fax: +44 1483 686850. E-mail: d.mulholland@surrey.ac.uk. 


\section{ABSTRACT:}

Ten new cembranolides, (-)-(1 $\left.R^{*}, 4 R^{*}, 10 R^{*}\right)$-4-methoxycembra-2E,7E,11Z-trien-20,10-olide (1), (-)-(1S*,4R*,10R*)-1-hydroxy-4-methoxycembra-2E,7E,11Z-trien-20,10-olide $\left(1 S^{*}, 4 S^{*}, 10 R^{*}\right)$-1,4-dihydroxycembra-2E,7E,11Z-trien-20,10-olide (3), (-)-(1S*,4S*,10R*)-1,4dihydroxycembra-2E,7E,11Z-trien-20,10-olide $\quad(4), \quad(+)-\left(10 R^{*}\right)$-cembra-1E,3E,7E,11Z,16pentaen-20,10-olide (5), (+)-(10R*)-cembra-1Z,3Z,7E,11Z,15-pentaen-20,10-olide (6), (+)$\left(5 R^{*}, 10 R^{*}\right)$-5-methoxycembra-1E,3E,7E,11Z,15-pentaen-20,10-olide (7), (+)$\left(1 S^{*}, 4 S^{*}, 7 \mathrm{R} *, 10 R^{*}\right)-1,4,7$-trihydroxycembra-2E,8(19),11Z-trien-20,10-olide (8), $(-)-$ $\left(1 S^{*}, 4 S^{*}, 7 S^{*}, 10 R^{*}\right)-1,4,7$-trihydroxycembra-2E,8(19),11Z-trien-20,10-olide $\quad(9), \quad$ and $(+)$ $\left(1 S^{*}, 4 R^{*}, 8 S^{*}, 10 R^{*}\right)-1,4,8$-trihydroxycembra-2E,6E,11Z-trien-20,10-olide (10), together with six known compounds, lupeol, 4(15)-eudesmene-1 $\beta, 6 \alpha$-diol, $\alpha$-glutinol, 24-ethylcholesta-4,22-dien3-one, (+)-( $\left.1 R^{*}, 10 R^{*}\right)$-cembra-2E,4E,7E,11Z-tetraen-20,10-olide and (+)-(1 $\left.R^{*}, 4 S^{*}, 10 R^{*}\right)-4$ hydroxycembra-2E,7E,11Z-trien-20,10-olide (4a), have been isolated from the leaves of Croton gratissimus. The acetyl derivative of $\mathbf{8}$ and $\mathbf{4 a}$ were evaluated against a chloroquine sensitive (CQS) strain of Plasmodium falciparum (D10). 
Croton gratissimus Burch. (C. zambesicus Müll. Arg.; C. microbotryus Pax.) (Euphorbiaceae) grows on stony hillsides as a semi-deciduous tree species throughout much of the warmer and drier regions from South Africa, northeastwards to the horn of Africa. The leaves of this plant are ground with goat fat and those of two other Croton L. species, and the resulting paste is heated on coals and the fumes inhaled as a cure for insomnia. ${ }^{1}$ A tea made from the leaves is taken for coughs in Botswana. ${ }^{2}$ Watt and Breyer-Brandwijk ${ }^{3}$ documented C. gratissimus as a remedy for fever, for treating bleeding gums and eye disorders, and as an ingredient used to "smoke" rheumatic patients. In South Africa, the leaves are dried and smoked for influenza, colds, and fevers. ${ }^{4}$ The traditional use of this species for treating fevers, intermittent or otherwise, indicates its likely application as an antimalarial, since it is employed as such within the malaria endemic-region of southern Africa. In Nigeria, bark infusions of the species (as $C$. zambesicus) are reported to treat malaria. ${ }^{5}$ Accordingly, crude dichloromethane extracts of South African leaves of $C$. gratissimus have previously been investigated for antiplasmodial activity in vitro and shown to have an $\mathrm{IC}_{50}$ value of $3.5 \mu \mathrm{g} / \mathrm{mL} ;{ }^{6}$ the constituent(s) responsible were not identified. The stem bark of Croton gratissimus has been reported to yield four cembranoids, namely, (+)-(1 $\left.R^{*}, 2 S^{*}, 7 S^{*}, 8 S^{*}, 12 R^{*}\right)-7,8$-epoxy-2,12-cyclocembra-3E,10Z-dien20,10-olide, (+)-( $\left(1 R^{*}, 10 R^{*}\right)$-cembra-2E,4E,7E,11Z-tetraen-20,10-olide, (+)-(1 $\left.R^{*}, 4 S^{*}, 10 R^{*}\right)$-4hydroxycembra-2E,7E,11Z-trien-20,10-olide (4a), and (-)-(1 $\left.R^{*}, 4 R^{*}, 10 R^{*}\right)$-4-hydroxycembra$2 E, 7 E, 11 Z$-trien-20,10-olide, in addition to lupeol, 4(15)-eudesmene-1 $\beta, 6 \alpha$-diol, and $\alpha$-glutinol. ${ }^{7}$

\section{RESULTS AND DISCUSSION}

The combined hexane and methylene chloride extracts (showed to be similar by TLC analysis) and the ethyl acetate extract of the leaves of $C$. gratissimus were separated using repeated column chromatography over silica gel to yield ten new cembranolides, 1-10, all of which were colorless oils. These were obtained together with six known compounds, eudesm4(15)-ene-1 $\beta, 6 \alpha$-diol, ${ }^{8} \quad \alpha$-glutinol, ${ }^{9}$ lupeol, ${ }^{10}(+)-\left(1 R^{*}, 4 S^{*}, 10 R^{*}\right)$-4-hydroxycembra-2E,7E,11Ztrien-20,10-olide (4a), and (+)-(1R*,10R*)-cembra-2E,4E,7E,11Z-tetraen-20,10-olide, which have been isolated previously from the bark of this species, ${ }^{7}$ and 24-ethylcholesta-4,22-dien-3one. ${ }^{11}$ NMR analysis showed that purified cembranolides are unstable on standing, but appear to be stable in the unpurified form. 
Compound 1 was identified as (-)-( $\left.1 R^{*}, 4 R^{*}, 10 R^{*}\right)$-4-methoxycembra-2E,7E,11Z-trien-20,10olide. The NMR spectra were very similar to those of $(-)-\left(1 R^{*}, 4 R^{*}, 10 R^{*}\right)$-4-hydroxycembra2E,7E,11Z-trien-20,10-olide (1a), previously isolated from the bark, for which the relative configuration was deduced by comparison with that of the crystalline $(+)-\left(1 R^{*}, 2 S^{*}\right.$, $7 S^{*}, 8 S^{*}, 12 R^{*}$ )-7,8-epoxy-2,12-cyclocembra-3E,10Z-dien-20,10-olide isolated from the same source. ${ }^{7}$ The HRMS indicated a molecular formula of $\mathrm{C}_{21} \mathrm{H}_{32} \mathrm{O}_{3}$ and the FTIR spectrum gave an absorption band at $1759 \mathrm{~cm}^{-1}$, consistent with an $\alpha, \beta$-unsaturated $\gamma$-lactone, a functional group present in all cembranolides isolated. ${ }^{12}$ The ${ }^{13} \mathrm{C}$ NMR spectrum displayed twenty-one carbon resonances, including those of a carbonyl carbon $\left(\delta_{\mathrm{C}} 174.2, \mathrm{C}-20\right)$, six olefinic carbons $\left(\delta_{\mathrm{C}} 149.6\right.$, $135.8,134.0,133.5,131.7$ and 129.4$)$, an oxymethine $\left(\delta_{\mathrm{C}} 80.3\right)$, and five methyl group carbon $\left(\delta_{\mathrm{C}}\right.$ $50.4, \delta_{\mathrm{C}} 20.7, \delta_{\mathrm{C}} 22.3, \delta_{\mathrm{C}} 19.5$, and $\left.\delta_{\mathrm{C}} 16.3\right)$. The ${ }^{1} \mathrm{H}$ NMR spectrum showed the presence of four olefinic proton resonances, one at $\delta_{\mathrm{H}} 6.98(\mathrm{brd}, J=1.8 \mathrm{~Hz}$ ) and three overlapping resonances at $\delta_{\mathrm{H}} 5.40(\mathrm{~m})$, a methoxy $\left(\delta_{\mathrm{H}} 3.15\right)$, four methyl group proton resonances at $\delta_{\mathrm{H}} 1.63(\mathrm{~s}), \delta_{\mathrm{H}} 1.25$ $(\mathrm{s}), \delta_{\mathrm{H}} 0.91(\mathrm{~d}, J=6.6 \mathrm{~Hz})$ and $\delta_{\mathrm{H}} 0.86(\mathrm{~d}, J=6.6 \mathrm{~Hz})$, one vinylic methyl group, and the presence of an isopropyl group, as in compounds previously isolated from the bark extract. ${ }^{7}$ The two methyl group proton doublets $\left(\mathrm{H}_{3}-16, \mathrm{H}_{3}-17\right)$ coupled to a methine proton resonance at $\delta_{\mathrm{H}}$ 1.62 (H-15), which was superimposed with the $\mathrm{H}-1$ resonance confirming the presence of isopropyl group. The $\mathrm{H}-1$ resonance was coupled to a two olefinic proton resonance at $\delta_{\mathrm{H}} 5.40$ (H-2, H-3) that showed no further coupling. The HMBC spectrum showed correlations of the H$2 / 3$ with the $\mathrm{C}-1\left(\delta_{\mathrm{C}} 48.9\right), \mathrm{C}-4\left(\delta_{\mathrm{C}} 77.2\right), \mathrm{C}-5\left(\delta_{\mathrm{C}} 43.7\right)$, and C-18 $\left(\delta_{\mathrm{C}} 22.3\right)$ resonances. The methoxy proton showed a correlation in the HMBC spectrum with the $\mathrm{C}-4$ resonance, indicating its attachment to C-4, and the C-4 resonance showed correlations with $\mathrm{H}_{3}-18$ and one of a pair of methylene group proton resonances at $\delta_{\mathrm{H}} 1.85(\mathrm{H}-5)$. This proton resonance showed coupling with $\delta_{\mathrm{H}} 2.35(\mathrm{~m})$ and $1.63(\mathrm{~m})$ at C-6, which, in turn, showed coupling with an olefinic proton $\left(\mathrm{H}-7, \delta_{\mathrm{H}} 5.40\right)$. The H-7 showed correlations in the HMBC spectrum with the C-6 $\left(\delta_{\mathrm{C}} 25.5\right)$, C$19\left(\delta_{\mathrm{C}} 16.3\right)$, and C-9 resonances $\left(\delta_{\mathrm{C}} 44.8\right)$. The magnitude of the ${ }^{13} \mathrm{C}$ NMR chemical shift of a vinylic methyl carbon resonance has been used by Crombie et al. ${ }^{13}$ and Olsson et al. ${ }^{14}$ to determine the configuration of a methyl-substituted double bond. Lange and Lee reported that a vinylic methyl group carbon resonance value of $<20 \mathrm{ppm}$ is indicative of an $E$ configuration, whereas a carbon resonance value of $>20 \mathrm{ppm}$ is indicative of a $Z$ configuration. ${ }^{15}$ As the chemical shift of the C-19 methyl carbon occurred at $\delta_{\mathrm{C}} 16.3$ an $E$ geometry is indicated for the 
$\Delta^{7}$ - double bond and hence the $\mathrm{H}_{3}-19$ methyl group was placed trans to H-7. ${ }^{13-15}$ The $\mathrm{H}_{2}-9$ resonances $(\delta 2.81,2.05, \mathrm{~m})$ were seen to be coupled with the $\mathrm{H}-10$ resonance $\left(\delta_{\mathrm{H}} 5.02\right.$, brs, $W_{1 / 2}$ $=19.7 \mathrm{~Hz})$ which showed further coupling with the $\mathrm{H}-11$ resonance $\left(\delta_{\mathrm{H}} 6.98\right)$ of the $\alpha, \beta-$ unsaturated $\gamma$-lactone. The lactone carbonyl carbon exhibited correlations in the HMBC spectrum with the $\mathrm{H}_{2}-13$ resonances $\left(\delta_{\mathrm{H}} 2.15,2.35, \mathrm{~m}\right)$. The $\mathrm{H}_{2}-13$ resonances were coupled to the two $\mathrm{H}-14$ resonances $\left(\delta_{\mathrm{H}} 1.95(\mathrm{~m}), 1.50(\mathrm{~m})\right.$, which showed coupling with the previously assigned H-1 resonance. H-1 was arbitrarily assigned as $\alpha$, as in compound $\mathbf{1 a}{ }^{7}$ and exhibited a correlation in the NOESY spectrum with the $\mathrm{H}_{3}-18$ methyl group indicating it was also $\alpha$ and then the methoxy group at $\mathrm{C}-4$ was in the $\beta$ configuration. A correlation between the methoxy group proton resonance and the isopropyl group resonances $\left(\mathrm{H}_{3}-16\right.$ and $\left.\mathrm{H}_{3}-17\right)$ was also observed, supporting a $\beta$ configuration of the isopropyl group. The broad multiplet $\left(W_{1 / 2}=19.7\right.$ $\mathrm{Hz}$ ) common in the series isolated from the bark and leaves of the same species indicated that $\mathrm{H}$ 10 is $\beta$ in all the compounds isolated. ${ }^{7}$ The H-10 resonance showed correlations in the NOESY spectrum with $\mathrm{H}-11$ and the $\mathrm{H}_{3}-19$ proton resonances, showing that both are on the $\beta$-face of the molecule, as illustrated in Figure 1. The conformation adopted by the molecule results in substituents attached to $\mathrm{sp}^{2}$ carbons, pointing above or below the general plane of the molecule. The specific rotation for compound 1 was found to be - 11.5. Therefore, the structure of compound 1 was determined as $(-)-\left(1 R^{*}, 4 R^{*}, 10 R^{*}\right)-4$-methoxycembra-2E,7E,11Z-trien-20,10olide.

The HRMS of compound 2 indicated a molecular formula of $\mathrm{C}_{21} \mathrm{H}_{32} \mathrm{O}_{4}$, and it was found to be the 1-hydroxy analogue of compound 1. In addition to a carbonyl stretch at $1754 \mathrm{~cm}^{-1}$, the IR spectrum showed an $\mathrm{OH}$-stretching at $3406 \mathrm{~cm}^{-1}$. The ${ }^{1} \mathrm{H}$ NMR and ${ }^{13} \mathrm{C}$ NMR resonances were similar to those of compound $\mathbf{1}$ except for a fully substituted oxygenated carbon resonance at $\delta_{\mathrm{C}}$ 76.7, instead of the $\mathrm{C}-1$ methine resonance. This was confirmed by HMBC correlations seen between the $\mathrm{C}-1$ resonance and the $\mathrm{H}-3, \mathrm{H}_{3}-16, \mathrm{H}_{3}-17$, and $\mathrm{H}-15$ resonances. Thus a hydroxy group was placed at C-1 in compound 2. The NOESY spectrum showed a correlation between the $\mathrm{H}-4 \beta$ methoxy group proton resonance $\left(\delta_{\mathrm{H}} 3.13, \mathrm{~s}\right)$ and the isopropyl group $\mathrm{H}_{3}-16\left(\delta_{\mathrm{H}} 0.91 \mathrm{~d}\right.$ $J=7.0 \mathrm{~Hz})$ and $\mathrm{H}_{3}-17\left(\delta_{\mathrm{H}} 0.88 \mathrm{~d} J=7.0 \mathrm{~Hz}\right)$ resonances. Thus, these groups were placed on the $\beta$ face, as in compound $\mathbf{1}$, and the hydroxy group was placed in the $\alpha$-orientation. The specific 
rotation for 2 was found to be - 46.4, and this compound was assigned as (-)-(1 $\left.S^{*}, 4 R^{*}, 10 R^{*}\right)-1$ hydroxy-4-methoxycembra-2E,7E,11Z- trien-20,10-olide.

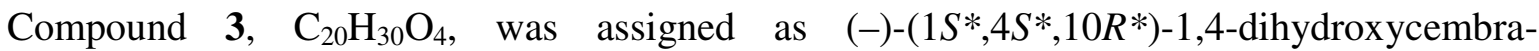
2E,7E,11Z-trien-20,10-olide. The IR spectrum gave an absorption band at $3421 \mathrm{~cm}^{-1}$ for a hydroxy group and an $\alpha, \beta$-unsaturated $\gamma$-lactone absorption band at $1757 \mathrm{~cm}^{-1}$, as was observed for $\mathbf{1}$ and 2. Compound $\mathbf{3}$ was found to be a 4-hydroxy analogue of $\mathbf{2}$. Its NMR spectra were very similar to those of $\mathbf{2}$, but the methoxy group proton resonance present in $\mathbf{1}$ and $\mathbf{2}$ was absent and the $\mathrm{C}-4$ and $\mathrm{C}-18$ resonances of 3 were shifted to $\delta_{\mathrm{C}} 74.3\left(\delta_{\mathrm{C}} 77.2\right.$ for 2$)$ and $\delta_{\mathrm{C}} 31.1\left(\delta_{\mathrm{C}} 23.0\right.$ for $\mathbf{2}$ ) respectively. The relative configuration for $\mathbf{3}$ was assumed to be the same as that of $\mathbf{2}$.

Compound 4, $\mathrm{C}_{20} \mathrm{H}_{30} \mathrm{O}_{4}$, was found to be the $\mathrm{C}-4$ epimer of 3 . This was confirmed by the correlation between the $\mathrm{H}_{3}-18(1.31, \mathrm{~s})$ resonance and the isopropyl group $\mathrm{H}_{3}-16\left(\delta_{\mathrm{H}} 0.90, \mathrm{~d}, J=\right.$ $6.9 \mathrm{~Hz})$ and $\mathrm{H}_{3}-17\left(\delta_{\mathrm{H}} 0.86, \mathrm{~d}, J=6.9 \mathrm{~Hz}\right)$ resonances in the NOESY spectrum. The ${ }^{13} \mathrm{C}$ NMR chemical shift for the oxygenated C-4 $\left(\delta_{\mathrm{C}} 72.9\right)$ and C-18 $\left(\delta_{\mathrm{C}} 28.8\right)$ for 4 differed slightly from those of $3\left(\delta_{\mathrm{C}} 74.3\right.$ and $\left.\delta_{\mathrm{C}} 31.1\right)$. The structure of compound 4 was proposed as (-)$\left(1 S^{*}, 4 S^{*}, 10 R^{*}\right)$-1,4-dihydroxycembra-2E,7E,11Z-trien-20,10-olide. Compound 4 is the $1 \alpha$ hydroxy derivative of compound $\mathbf{4 a}$, previously isolated from the bark, and re-isolated from the leaves in the present investigation.

Compound 5, $\mathrm{C}_{20} \mathrm{H}_{26} \mathrm{O}_{2}$, was identified as (+)-(10R*)-cembra-1E,3E,7E,11Z,15-pentaen20,10-olide. The IR spectrum showed no OH band and the NMR spectra differed in having an additional three trisubstituted double bonds and a terminal methylene group. The observation of coupled terminal methylene group proton resonances at $\delta_{\mathrm{H}} 5.02(\mathrm{~s})$ and $\delta_{\mathrm{H}} 5.08(\mathrm{~s})$ and a vinyl methyl three proton resonance at $\delta_{\mathrm{H}} 1.96$, instead of the $\mathrm{H}_{3}-16$ and $\mathrm{H}_{3}-17$ doublets present in the ${ }^{1} \mathrm{H}$ NMR spectra of compounds $\mathbf{1 - 4}$, indicated the presence of an isopropenyl group at $\mathrm{C}-1$ in $\mathbf{5}$. The C-1 resonance $\left(\delta_{\mathrm{C}} 142.9\right)$ showed correlations in the HMBC spectrum with the two $\mathrm{H}_{2}-16$ and $\mathrm{H}_{3}-17$ proton resonances and resonances at $\delta_{\mathrm{H}} 6.43(\mathrm{H}-2, J=11.5 \mathrm{~Hz})$ and $6.06(\mathrm{H}-3$, $J=11.5 \mathrm{~Hz})$. The corresponding C-3 resonance $\left(\delta_{\mathrm{C}} 123.6\right)$ correlated in the HMBC spectrum with the $\mathrm{H}_{3}-18$ vinyl methyl group proton resonance at $\delta_{\mathrm{H}} 1.79$, indicating a conjugated $\Delta^{1}, \Delta^{3}-$ system. The NOESY spectrum showed a correlation between the terminal methylene proton 
resonances and the $\mathrm{H}-2$ resonance and between the $\mathrm{H}-2$ resonance and the $\mathrm{H}_{3}-18$ methyl group proton resonance. Thus it was deduced that both double bonds were $E$. The chemical shift of $\delta_{\mathrm{C}}$ 16.5 for C-18 supported this deduction. ${ }^{15}$ These coupling constants and chemical shifts were in agreement with those found for crotocembraneic acid and neocrotocembraneic acid that also have a $\Delta^{1}, \Delta^{3}$-double bond system. ${ }^{16,17}$ A specific rotation value of +24.2 for 5 was determined.

Compound 6, $\mathrm{C}_{20} \mathrm{H}_{26} \mathrm{O}_{2}$, was found to be a geometric isomer of $\mathbf{5}$. The most significant difference between the ${ }^{13} \mathrm{C}$ NMR spectra of these two compounds were the differences in chemical shifts for the C-5 and C-18 carbon resonances, which occurred at $\delta_{\mathrm{C}} 40.3$ and $\delta_{\mathrm{C}} 16.5$, respectively, in 5 but at $\delta_{\mathrm{C}} 31.4$ and $\delta_{\mathrm{C}} 24.0$ in $\mathbf{6}$. The value of the chemical shift of $\delta_{\mathrm{C}} 24.0$ for the C-18 vinylic methyl group carbon resonance was indicative of a $Z$ configuration of the $\Delta^{3}$ double bond ${ }^{15}$ and this was confirmed by correlations in the NOESY spectrum between H-3 and the $\mathrm{H}_{3}-18$ resonance. Specific rotation value of +18.6 was measured for $\mathbf{6}$. This compound was assigned as (+)-(10R*)-cembra-1Z,3Z,7E,11Z,15-pentaen-20,10-olide.

Compound 7, $\mathrm{C}_{21} \mathrm{H}_{30} \mathrm{O}_{3}$, as in compound 5 has $\Delta^{1}, \Delta^{3}$ conjugated system with isopropyl substituent at $\mathrm{C}-1$ and methoxy group at $\mathrm{C}-5$. The methoxy group three-proton singlet resonance $\left(\delta_{\mathrm{H}} 3.26\right)$ showed a correlation in the HMBC spectrum with an oxymethine resonance $\left(\delta_{\mathrm{C}} 86.0\right)$, which showed a further correlation with the $\mathrm{H}_{3}-18$ proton resonance $\left(\delta_{\mathrm{C}}\right.$ 1.76). The corresponding C-18 resonance was shifted markedly upfield to $\delta_{\mathrm{C}} 12.5$. The NOESY spectrum exhibited correlations between the $\mathrm{H}-10 \beta$ resonance and the $\mathrm{H}_{3}-19$ resonance, which, in turn, correlated with one of the H-6 $\left(\delta_{\mathrm{H}} 2.40\right)$ and $\mathrm{H}-5\left(\delta_{\mathrm{H}} 3.59 \mathrm{dd} J=3.60,7.80 \mathrm{~Hz}\right)$ resonances. Thus, these protons were assigned as $\beta$. Specific rotation value of +24.2 was measured for 7 . This compound was assigned as $(+)-\left(5 R^{*}, 10 R^{*}\right)-5$-methoxycembra- $1 E, 3 E, 7 E, 11 Z, 15$-pentaen20,10-olide.

Compounds 8 and 9 were found to be C-7 epimers of each other and HRESIMS analysis indicated both had a molecular formula of $\mathrm{C}_{20} \mathrm{H}_{30} \mathrm{O}_{3}$. As with compound $\mathbf{4}$, they both had an isopropyl group at C-1, and hydroxy groups at C-1 $\alpha$ and $\mathrm{C}-4 \alpha$, but the $\Delta^{7}$-double bond had moved to the 8,19-position and a hydroxy group was found to be present at C-7. For compound 8 this was confirmed by correlations seen in the HMBC spectrum between the C- 8 resonance $\left(\delta_{\mathrm{C}}\right.$ 
142.0) and one of the two methylene protons at C-19 resonances $\left(\delta_{\mathrm{H}} 5.29\right)$, and between the $\mathrm{C}-19$ resonance $\left(\delta_{\mathrm{C}} 29.9\right)$ and $\mathrm{H}-7\left(\delta_{\mathrm{H}} 4.16, \mathrm{t}, J=7.1 \mathrm{~Hz}\right)$ and one of the $\mathrm{H}-9$ resonances $\left(\delta_{\mathrm{H}} 2.40\right)$. In the COSY spectrum H-7 resonance coupled to the two H-6 proton resonances, which were further coupled to the two H-5 resonances in the COSY spectrum. Similar correlations were observed in the NMR spectra of 9. The ${ }^{13} \mathrm{C}$ NMR chemical shift values for C-6, C-7, and C-19 differed considerably between compounds 8 and $\mathbf{9}$ (see Table 2). As with compound 4, the relative configuration of $\mathbf{8}$ and $\mathbf{9}$ could be determined using the NOESY spectrum. In both cases, correlations could be seen between the isopropyl group methyl and $\mathrm{H}_{3}-18$ proton resonances and so these groups were assigned as $\beta$. For 8 , correlations were also observed in the NOESY spectrum between the $\mathrm{H}_{3}-18$ methyl group and the proton resonance and the $\mathrm{H}-7$ proton resonance, which showed, in turn, a correlation with the $\mathrm{H}_{2}-19$ proton resonance. The latter correlated with the $\mathrm{H}-11$ proton resonance, which, in turn showed a correlation with the $\mathrm{H}-10$ resonance, establishing these as occurring on the $\beta$ face, and therefore the hydroxy groups at $\mathrm{C}-1$, $\mathrm{C}-4$ and $\mathrm{C}-7$ as $\alpha$. The specific rotation for compound $\mathbf{8}$ was +100 . Compound $\mathbf{8}$ was therefore assigned as $(+)-\left(1 S^{*}, 4 S^{*}, 7 R^{*}, 10 R^{*}\right)-1,4,7$-trihydroxycembra-2E,8(19),11Z-trien-20,10-olide. The change in the ${ }^{13} \mathrm{C}$ NMR chemical shifts for the oxymethine C-7 from $\delta_{\mathrm{C}} 89.8$ in compound 8 and $\delta_{\mathrm{C}} 76.8$ for compound 9 indicated different configuration at C-7. This was confirmed by a lack of any correlation between $\mathrm{H}-7$ and $\mathrm{H}_{3}-18$ in the NOESY spectrum of 9. Thus the C-7 hydroxy group was assigned as $\beta$ in $\mathbf{9}$. The specific rotation of $\mathbf{9}$ was -24.8 and it was assigned

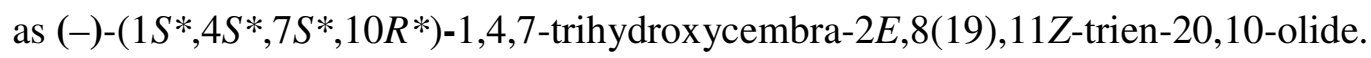

Compound 10, $\mathrm{C}_{20} \mathrm{H}_{30} \mathrm{O}_{5}$, displayed in its NMR spectra, in addition to resonances ascribable to a $\alpha, \beta$-unsaturated $\gamma$-lactone, three oxygenated fully substituted carbon resonances and two alkene double bonds. The resonance at $\delta_{\mathrm{C}} 76.8$ showed a correlation with the two isopropyl group methyl doublets in the HMBC spectrum and was assigned to $\mathrm{C}-1$. This resonance also showed correlation, with two olefinic proton resonances at $\delta_{\mathrm{H}} 5.45, \mathrm{~d}, J=16.2 \mathrm{~Hz}$ and $5.71, \mathrm{~d}, J$ $=16.2 \mathrm{~Hz}$ which could be assigned as $\mathrm{H}-2$ and $\mathrm{H}-3$ of a trans-disubstituted double bond. The C3 resonance showed correlations with the C-4 oxygenated carbon $\left(\delta_{\mathrm{C}} 72.4\right)$, the C-18 methyl group carbon resonances, and the $\mathrm{CH}_{2}-5$ carbon resonance. The corresponding $\mathrm{H}-5$ resonances showed coupling with the H-6 olefinic resonance $\left[\delta_{\mathrm{H}} 5.64(\mathrm{~m})\right]$, which was further coupled to the $\mathrm{H}-7$ resonance $\left(\delta_{\mathrm{H}} 5.55, \mathrm{~d}, J=16.4 \mathrm{~Hz}\right)$ of the second trans-disubstituted double bond. The H-7 
resonance showed correlations in the HMBC spectrum with the oxygenated C- 8 resonance $(\delta$ 83.6) and the C-19 methyl group proton resonance $\left(\delta_{\mathrm{C}} 25.8\right)$

The relative configuration of $\mathbf{1 0}$ was assigned using the NOESY spectrum. The two methyl proton resonances of the isopropyl group $\mathrm{H}_{3}-16\left(\delta_{\mathrm{C}} 0.84, \mathrm{~d}, J=6.8 \mathrm{~Hz}\right)$ and $\mathrm{H}_{3}-17(\delta 0.87, \mathrm{~d}, J=$ $6.8 \mathrm{~Hz})$ showed correlation, with the $\mathrm{H}_{3}-18(\delta 1.37, \mathrm{~s})$ methyl proton resonance as was seen for compounds 4,8 and 9 and were likewise placed on the $\beta$ - face, as was H-10. No correlations were seen in the NOESY spectrum with the $\mathrm{H}_{3}-19$ resonance, and so this group was assigned as $\alpha$ with the C-8 hydroxy group $\beta$. Specific rotation of +32.0 was determined and $\mathbf{1 0}$ was assigned as $(+)-\left(1 S^{*}, 4 R^{*}, 8 S^{*}, 10 R^{*}\right)-1,4,8$-trihydroxycembra-2E,6E,11Z-trien-20,10-olide.

The acetate derivative of $\mathbf{8}$ was prepared in an attempt to produce a crystalline product for single crystal X-ray analysis, or a more stable compound for screening. Unfortunately, the derivative was not crystalline but was stable enough to undergo in vitro antiplasmodial screening against $P$. falciparum (CQS) D10 strain. Compounds 4a and 8a exhibited $\mathrm{IC}_{50}$ values of 20.8 and $13.5 \mu \mathrm{g} / \mathrm{mL}$, respectively, compared to chloroquine ( $\mathrm{IC}_{50} 27.0 \mathrm{ng} / \mathrm{mL}$ ).

\section{EXPERIMENTAL SECTION}

General Experimental Procedures. Specific rotations were measured at room temperature in chloroform using a JASCO P-1020 polarimeter and IR spectra were recorded using a PerkinElmer (2000 FTIR) spectrometer. Samples were dissolved in chloroform and analyzed using $\mathrm{NaCl}$ plates. NMR spectra were recorded on a Bruker AVANCE 500 NMR spectrometer in deuteriochloroform $\left(\mathrm{CDCl}_{3}\right)$ and the chemical shifts were recorded in ppm (parts per million) relative to the deuteriochloroform central line at $\delta 7.260$ in the ${ }^{1} \mathrm{H}$ NMR spectrum and at $\delta 77.23$ in the ${ }^{13} \mathrm{C}$ NMR spectrum. HRESIMS were determined using a Bruker MicroToF mass spectrometer, with an Agilent 1100 HPLC used to introduce the samples.

Plant Material. Leaves of Croton gratissimus Burch. var. gratissimus were collected in August 2005 from a mature tree cultivated on the campus of the University of KwaZulu-Natal, Durban, South Africa, by N. Crouch. A voucher (Crouch 1051) retained for verification purposes at the KwaZulu-Natal Herbarium (NH). 
Extraction and Isolation. The ground leaves (189 g) of $C$. gratissimus was extracted using a Soxhlet apparatus for $24 \mathrm{~h}$ successively using hexane, methylene chloride, ethyl acetate and methanol. After evaporation of the solvent in vacuo the following extracts were obtained: hexane (8.46 g), methylene chloride (2.55 g), ethyl acetate (8.84 g), and methanol (25.57 g). The hexane and methylene chloride extracts were combined due to their similar TLC bands. The combined hexane and methylene chloride extracts as well as the ethyl acetate extracts were examined in this study. Column chromatography of combined hexane and methylene chloride extracts and ethyl acetate extract over silica gel (Merck 9385) using a $5 \mathrm{~cm}$ diameter by $60 \mathrm{~cm}$ length gravity column, collecting fractions $(75 \mathrm{~mL}$ each) using a hexane/methylene chloride step gradient starting with $100 \%$ hexane and gradually increasing the methylene chloride concentration to $100 \%$, followed by $5 \%$ methanol in methylene chloride, was used to separate the constituents. Final purification was undertaken over silica gel using a $1 \mathrm{~cm}$ diameter by 60 $\mathrm{cm}$ length gravity column with different solvents as indicated below for each compound. The combined hexane and methylene chloride extracts gave the following compounds: fractions 4054 were repurified using $\mathrm{CH}_{2} \mathrm{Cl}_{2} /$ hexane, $1: 1$ to give $5(30 \mathrm{mg})$ and $6(19 \mathrm{mg})$; fractions $60-73$ gave $\alpha$-glutinol (47 mg) using $100 \% \mathrm{CH}_{2} \mathrm{Cl}_{2}$, and fractions $100-127$ gave 4 (30 mg) using $100 \% \mathrm{CH}_{2} \mathrm{Cl}_{2}$. The ethyl acetate extract gave: fractions $10-19\left(20 \% \mathrm{CH}_{2} \mathrm{Cl}_{2}\right.$ in hexane) gave (+)-(1 $\left.R^{*}, 10 R^{*}\right)$-cembra-2E, 4E, 7E,11Z-tetraen-20, 10-olide (13 mg); fractions 21-26 (100\% $\mathrm{CH}_{2} \mathrm{Cl}_{2}$ ) gave 24-ethylcholesta-4,22-dien-3-one (31.5 mg); fractions 27-40 (100\% $\left.\mathrm{CH}_{2} \mathrm{Cl}_{2}\right)$ gave lupeol (26 mg) and $2(17.0 \mathrm{mg})$; fractions $45-67\left(100 \% \mathrm{CH}_{2} \mathrm{Cl}_{2}\right)$ gave additional $\mathbf{3}(10 \mathrm{mg})$ and eudesm-4(15)-ene-1 $\beta, 6 \alpha$-diol (15 mg); fractions $78-123\left(3 \% \mathrm{MeOH} / 97 \% \mathrm{CH}_{2} \mathrm{Cl}_{2}\right)$ gave (+)$\left(1 R^{*}, 4 S^{*}, 10 R^{*}\right)$-4-hydroxycembra-2E,7E,11Z-trien-20,10-olide (4a), (13 mg), 8 (9.7 mg), 9 (6.5 $\mathrm{mg}$ ), and 10 (30 mg). The ${ }^{1} \mathrm{H}$ and ${ }^{13} \mathrm{C}$ NMR spectroscopic data for all new compounds are shown in Tables 1 and 2, respectively.

(-)-(1R*,4R*,10R*)-4-Methoxycembra-2E,7E,11Z-trien-20,10-olide (1): Colorless oil; $[\alpha]_{\mathrm{D}}{ }^{24}$ - 11.5 (c 0.0013, $\mathrm{CHCl}_{3}$ ); IR (neat) $v_{\max } 2938,2853,1759 \mathrm{~cm}^{-1}$; HRESIMS m/z $355.1882[\mathrm{M}+$ $\mathrm{Na}]^{+}$(calcd for $\mathrm{C}_{21} \mathrm{H}_{32} \mathrm{O}_{3} \mathrm{Na}, 332.1984$ ). 
(-)-(1S*,4R*,10R*)-1-Hydroxy-4-methoxycembra-2E,7E,11Z- trien-20,10-olide

(2):

Colorless oil; $[\alpha]_{\mathrm{D}}{ }^{24}-46.4$ (c 0.0076, $\mathrm{CHCl}_{3}$ ); IR (neat) $v_{\max } 3406,2929,2861,1754 \mathrm{~cm}^{-1}$; HRESIMS $m / z, 371.2188[\mathrm{M}+\mathrm{Na}]^{+}$(calcd for $\mathrm{C}_{21} \mathrm{H}_{32} \mathrm{O}_{4} \mathrm{Na}, 348.2300$ ).

(-)-(1S*,4S*,10R*)-1,4-Dihydroxycembra-2E,7E,11Z-trien-20,10-olide (3): Colorless oil; $[\alpha]_{\mathrm{D}}{ }^{24}-12.9\left(c 0.004, \mathrm{CHCl}_{3}\right.$ ); IR (neat) $v_{\max } 3421,2938,2851,1757$; HRESIMS $\mathrm{m} / \mathrm{z} 357.2027$ $[\mathrm{M}+\mathrm{Na}]^{+}$(calcd for $\left.\mathrm{C}_{20} \mathrm{H}_{30} \mathrm{O}_{4} \mathrm{Na}, 321.2144\right)$.

(-)-(1S*,4S*,10R*)-1,4-Dihydroxycembra-2E,7E,11Z-trien-20,10-olide (4): Colorless oil; $[\alpha]_{\mathrm{D}}{ }^{24}-42.0\left(c 0.0075, \mathrm{CHCl}_{3}\right)$; IR (neat) $v_{\max } 3429,1740 \mathrm{~cm}^{-1}$; HRESIMS $\mathrm{m} / z 357.2037 \mathrm{M}+$ $\mathrm{Na}]^{+}$(calcd for $\mathrm{C}_{20} \mathrm{H}_{30} \mathrm{O}_{4} \mathrm{Na}, 357.2042$ ).

(+)-(10R*)-Cembra-1E,3E,7E,11Z,16-pentaen-20,10-olide (5): Colorless oil; $[\alpha]_{\mathrm{D}}{ }^{24}+24.2(c$ $0.0004, \mathrm{CHCl}_{3}$ ); IR (neat) $v_{\max } 2959,2863,1753 \mathrm{~cm}^{-1}$; HRESIMS $\mathrm{m} / z 321.1825\left[\mathrm{M}+\mathrm{Na}^{+}\right.$ (calcd for $\mathrm{C}_{20} \mathrm{H}_{26} \mathrm{ONa}, 321.1831$ ).

(+)-(10R*)-Cembra-1Z,3Z,7E,11Z,15-pentaen-20,10-olide (6): Colorless oil; $[\alpha]_{\mathrm{D}}{ }^{24}+18.6(c$ $0.007, \mathrm{CHCl}_{3}$ ); IR (neat) $v_{\max } 3063,2923,2856,1749 \mathrm{~cm}^{-1}$; HRESIMS $\mathrm{m} / z 321.1819[\mathrm{M}+\mathrm{Na}]^{+}$ (calcd for $\mathrm{C}_{20} \mathrm{H}_{26} \mathrm{ONa}, 321.1831$ ).

(+)-(5R*,10R*)-5-Methoxycembra-1E,3E,7E,11Z,15-pentaen-20,10-olide (7): Colorless oil; $[\alpha]_{\mathrm{D}}{ }^{24}+27.6\left(c 0.0039, \mathrm{CHCl}_{3}\right) ;$ IR (neat) $v_{\max } 2934,2828,1759 \mathrm{~cm}^{-1}$; HRESIMS $\mathrm{m} / \mathrm{z} 339.1923$ $[\mathrm{M}+\mathrm{Na}]^{+}$(calcd for $\mathrm{C}_{21} \mathrm{H}_{30} \mathrm{O}_{3} \mathrm{Na}, 330.2195$ )

(+)-(1S*,4S*,7R*,10R*)-1,4,7-Trihydroxycembra-2E,8(19),11Z-trien-20,10-olide

Colorless oil; $[\alpha]_{\mathrm{D}}{ }^{24}+100\left(c 0.0004, \mathrm{CHCl}_{3}\right)$; IR (neat) $v_{\max } 3411,1733,1645,847 \mathrm{~cm}^{-1}$; HRESIMS $m / z 373.1978[\mathrm{M}+\mathrm{Na}]^{+}$(calcd for $\mathrm{C}_{20} \mathrm{H}_{30} \mathrm{O}_{5} \mathrm{Na}, 373.1991$ ).

Acetylation of (+)-(1S*,4S*,7R*,10R*)-1,4,7-Trihydroxycembra-2E,8(19),11Z-trien-20,10olide $(8)$. Compound $8(5 \mathrm{mg})$ was dissolved in pyridine $(1 \mathrm{~mL})$ and acetic anhydride $(1 \mathrm{~mL})$ and left to stand for $12 \mathrm{~h}$. $\mathrm{MeOH}(2 \times 5 \mathrm{~mL})$ was added and solvent was removed under vacuum to yield (+)-(1S*,4S*,7R*,10R*)-7-acetoxy-1,4-dihydroxycembra-2E,8(19),11Z-trien-20,10-olide (8a). The ${ }^{1} \mathrm{H}$ and ${ }^{13} \mathrm{C}$ NMR spectroscopic data of $\mathbf{8 a}$ are shown in Tables 1 and 2, respectively.

(-)-(1S*,4S*,7S*,10R*)-1,4,7-trihydroxycembra-2E,8(19),11Z-trien-20,10-olide

Colorless oil; $[\alpha]_{\mathrm{D}}{ }^{24}-24.8\left(c 0.004, \mathrm{CHCl}_{3}\right)$; IR (neat) $v_{\max } 3428,1739 \mathrm{~cm}^{-1}$; HRESIMS $\mathrm{m} / \mathrm{z}$ $373.1980[\mathrm{M}+\mathrm{Na}]^{+}$(calcd for $\mathrm{C}_{20} \mathrm{H}_{30} \mathrm{O}_{3} \mathrm{Na}, 373.1991$ ). 
Colorless oil; $[\alpha]_{\mathrm{D}}{ }^{24}+32.0\left(c 0.001, \mathrm{CHCl}_{3}\right)$; IR (neat) $v_{\max } 3390,1730 \mathrm{~cm}^{-1}$; HRESIMS $\mathrm{m} / \mathrm{z}$ $373.1964[\mathrm{M}+\mathrm{Na}]^{+}$(calcd for $\mathrm{C}_{20} \mathrm{H}_{30} \mathrm{O}_{5} \mathrm{Na}, 373.1991$ ).

In Vitro Antiplasmodial Activity of Compounds 4a and 8a against $P$. falciparum (CQS) D10 Strain. The test samples were tested in duplicate against the chloroquine-sensitive (CQS) strain of Plasmodium falciparum (D10). Continuous in vitro cultures of asexual erythrocyte stages of $P$. falciparum were maintained using a modified method of Trager and Jensen. ${ }^{18}$ Quantitative assessment of antiplasmodial activity in vitro was determined via the parasite lactate dehydrogenase assay using a modified method described by Makler. ${ }^{19}$ The two extracts were dissolved and diluted to give a $2 \mathrm{mg} / \mathrm{mL}$ stock solution in $10 \%$ DMSO and sonicated to enhance solubility. Samples were tested as a suspension if not completely dissolved. Stock solutions were stored at $-20^{\circ} \mathrm{C}$. Further dilutions were prepared on the day of the experiment in complete medium. Chloroquine was used as the reference drug in all experiments. A full dose-response was performed for all compounds to determine the concentration inhibiting $50 \%$ of parasite growth $\left(\mathrm{IC}_{50}\right.$ - value). Test samples were tested at a starting concentration of $100 \mu \mathrm{g} / \mathrm{mL}$, which was serially diluted 2-fold in complete medium to give 10 concentrations, with the lowest concentration being $0.2 \mu \mathrm{g} / \mathrm{mL}$. Chloroquine was tested at a starting concentration of $100 \mathrm{ng} / \mathrm{mL}$. The highest concentration of solvent to which the parasites were exposed had no measurable effect on the parasite viability (data not shown). The $\mathrm{IC}_{50}$ values were obtained using a nonlinear dose-response curve fitting analysis using Graph Pad Prism v. 4.0 software.

\section{ASSOCIATED CONTENT}

The ${ }^{1} \mathrm{H}$ and ${ }^{13} \mathrm{C}$ NMR spectra of compounds 1-10 are available via the Internet at http://pubs.acs.org

\section{AUTHOR INFORMATION}

Corresponding author. "Tel: +441483 686827. Fax: +44 1483 686850. E-mail: D.mulholland@surrey.ac.uk. 


\section{ACKNOWLEDGEMENT}

This research was funded by the University of Surrey through a Ph.D. studentship for M.L. and the South African National Research Foundation (NRF).

\section{REFERENCES}

(1) Palmer, E.; Pitman, N. Trees of Southern Africa. Vol 2; A.A. BalKema: Cape Town, 1972; p 1135.

(2) Hedberg, I.; Staugård, F. Traditional Medicine in Botswana. Traditional Medicinal Plants; Ipeleng Publishers: Gaborone, 1989; p 101.

(3) Watt, J. M.; Breyer-Brandwijk, M. G. The Medicinal and Poisonous Plants of Southern and Eastern Africa, E. \& S. Livingstone, Ltd: Edinburgh and London, 1962; p 400.

(4) Mabogo, D. E. N. The Ethnobotany of the Vhavenda. M.Sc. Thesis, University of Pretoria, Pretoria, 1990.

(5) Burkill, H. M. The Useful Plants of West Tropical Africa, Vol. 2, Families E-I; Royal Botanic Gardens, Kew: Richmond, 1994; p 51.

(6) Clarkson, C.; Maharaj, V. J.; Crouch, N. R.; Grace, O. M.; Pillay, P.; Matsabisa, M. G.; Bhagwandin, N.; Smith, P. J.; Folb, P. I. Ethnopharmacol. 2004, 92, 177-191.

(7) Mulholland, D. A.; Langat, M. K.; Crouch, N. R.; Coley, H. M.; Mutambi, E. M.; Nuzillard, J. M. Phytochemistry 2010, 71, 1381 - 1386.

(8) Sun, Z.; Chen, B.; Zhang, S.; Hu, C. J. Nat. Prod. 2004, 67, 1975 - 1979.

(9) Olea, R. S. G.; Torres, L. M. B.; Roque, L. C.; Roque, N. F. Magn. Reson. Chem. 1993, $32,378-379$.

(10) Burns, D.; Reynolds, W. F.; Buchanan, G.; Reese, P. B.; Enriquez, R. G. Mag. Reson. Chem. 2000, 38, 488-493.

(11) Georges, P.; Sylvestre, M.; Ruegger, H.; Bourgeois, P. Steroids 2006, 71, 647 - 652.

(12) Pavia, D. L.; Lampman, G. M.; Kriz, G. S.; Vyvan, J. R. Introduction to Spectroscopy, Brooks/Cole; Belmont, CA. 2009; p 69.

(13) Crombie, L.; King, R. W.; Whiting, D. A. J. Chem. Soc., Perkin Trans. 1, 1975, 913 915.

(14) Olsson, E.; Berg, J.; Wahlberg, I. Tetrahedron 1993, 49, 4975- 4992.

(15) Lange, L. G.; Lee, M. Magn. Reson. Chem. 1986, 24, 656 - 658. 
(16) Roengsumran, S.; Achayindee, S.; Petsom, A.; Pudhom, K.; Singtothong, P.; Surachetapan, C.; Vilaivan, T. J. Nat. Prod. 1998, 61, 652-654.

(17) Pudhom, K.; Vilaivan, T.; Ngamrojanavanich, N.; Dechangvipart, S.; Sommit, D.; Petsom, A.; Roengsumran, S. J. Nat. Prod. 2007, 70, 659-661.

(18) Trager, W.; Jensen, J. B. Science 1976, 193, 673 - 675.

(19) Makler, M. T.; Ries J. M.; Williams, J. A.; Bancroft, J. E.; Piper, R. C.; Gibbins, B. L.; Hinrichs, D. J. Am. Soc. Trop. Med. Hyg. 1993, 48, 739-741. 


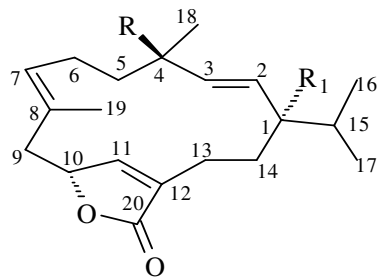

$1 \mathrm{R}=\mathrm{OCH}_{3}, \mathrm{R}_{1}=\mathrm{H}$

1a $\mathrm{R}=\mathrm{OH}, \mathrm{R}_{1}=\mathrm{H}$

$2 \mathrm{R}=\mathrm{OCH}_{3}, \mathrm{R}_{1}=\mathrm{OH}$

$3 \mathrm{R}=\mathrm{OH}, \mathrm{R}_{1}=\mathrm{OH}$
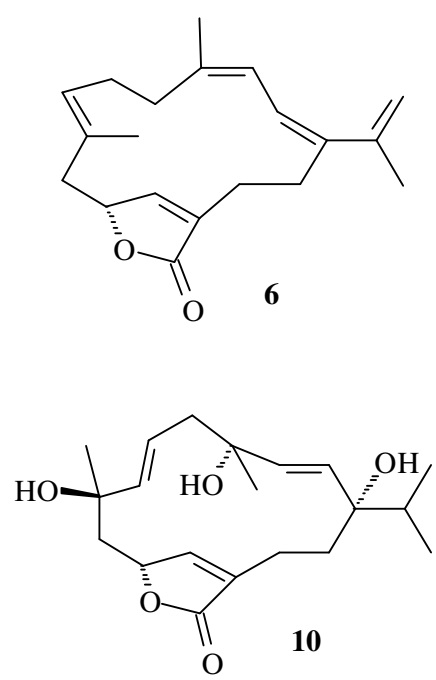
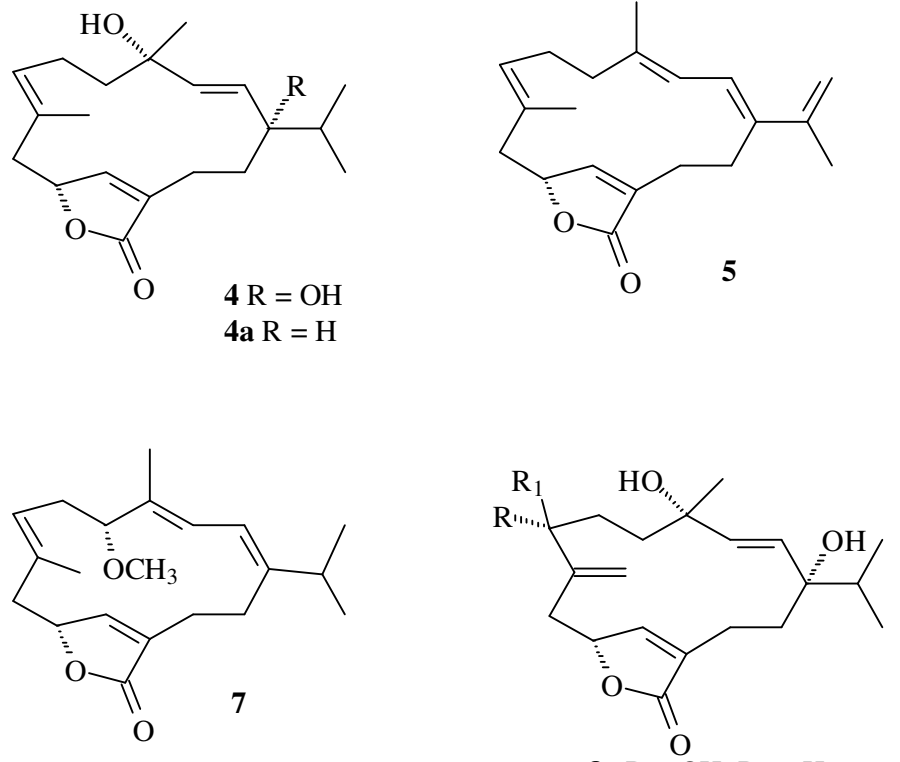

$8 \mathrm{R}=\mathrm{OH} \quad \mathrm{R}_{1}=\mathrm{H}$ 8a $\mathrm{R}=\mathrm{OAc} \quad \mathrm{R}_{1}=\mathrm{H}$

$9 \mathrm{R}=\mathrm{H} \quad \mathrm{R}_{1}=\mathrm{OH}$

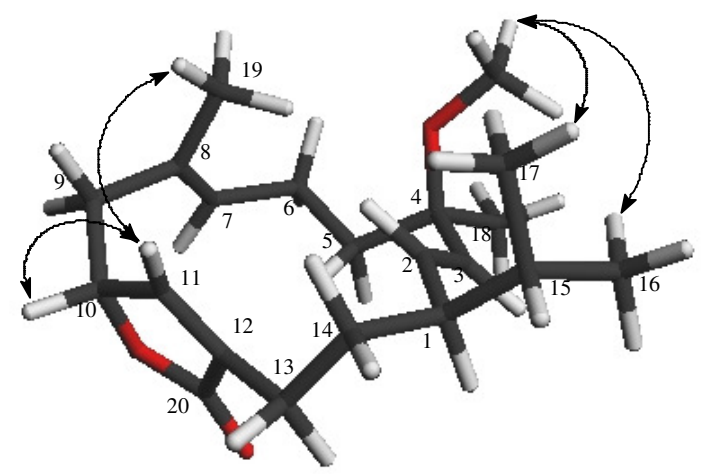

Figure 1: Selected NOE correlations for compound 1 
Table 1. ${ }^{1} \mathrm{H}$ NMR Spectroscopic Data of Compounds 1-10 and 8a in $\mathrm{CDCl}_{3}$

\begin{tabular}{|c|c|c|c|c|c|c|c|c|c|c|c|}
\hline Number & 1 & 2 & 3 & 4 & 5 & 6 & 7 & 8 & 9 & 10 & $\mathbf{8 a}$ \\
\hline 1 & $1.62^{a}$ & - & - & - & - & - & - & - & - & - & - \\
\hline 2 & $5.40^{a}$ & $5.51 \mathrm{~d}(16.0)$ & $5.73 \mathrm{~d}(15.5)$ & $5.57 \mathrm{~d}(16.1)$ & $6.43 \mathrm{~d}(11.5)$ & $6.45 \mathrm{~d}(11.0)$ & $6.19^{a}$ & $5.46 \mathrm{~d}(16.2)$ & $5.47 \mathrm{~d}(16.1)$ & $5.45 \mathrm{~d}(16.2)$ & $5.44 \mathrm{~d}(16.2)$ \\
\hline 3 & $5.40^{a}$ & $5.74 \mathrm{~d}(16.0)$ & $5.77 \mathrm{~d}(15.5)$ & $5.76 \mathrm{~d}(16.1)$ & $6.06 \mathrm{~d}(11.5)$ & $6.29 \mathrm{~d}(11.0)$ & $6.20^{a}$ & $5.83 \mathrm{~d}(16.2)$ & $5.80 \mathrm{~d}(16.1)$ & $5.71 \mathrm{~d}(16.2)$ & $5.80 \mathrm{~d}(16.2)$ \\
\hline 4 & - & - & - & - & - & - & - & - & - & - & - \\
\hline $5 \alpha$ & $2.00 \mathrm{~m}$ & $2.00 \mathrm{~m}$ & $1.81 \mathrm{~m}$ & $1.83 \mathrm{~m}$ & $2.26 \mathrm{~m}$ & $2.79^{a}$ & $\begin{array}{c}3.59 \mathrm{dd}(3.6 \\
7.8)\end{array}$ & $1.79 \mathrm{~m}$ & $1.79 \mathrm{~m}$ & $\begin{array}{c}2.47 \mathrm{dd}(3.4, \\
14.5)\end{array}$ & $1.76^{a}$ \\
\hline $5 \beta$ & $1.40 \mathrm{~m}$ & $1.38 \mathrm{~m}$ & $1.65 \mathrm{~m}$ & $1.58 \mathrm{~m}$ & $2.17^{a}$ & $2.00 \mathrm{dt}(4.0,3.6)$ & & $1.35 \mathrm{~m}$ & $1.30 \mathrm{~m}$ & $2.37 \mathrm{~m}$ & $1.31 \mathrm{~m}$ \\
\hline $6 \alpha$ & $2.35 \mathrm{~m}$ & $2.35 \mathrm{~m}$ & $2.20 \mathrm{~m}$ & $2.21 \mathrm{~m}$ & $2.31 \mathrm{~m}$ & $2.52 \mathrm{~m}$ & $2.40^{a}$ & $1.68^{a}$ & $1.70^{a}$ & $5.64 \mathrm{~m}$ & $1.81 \mathrm{~s}$ \\
\hline $6 \beta$ & $2.35 \mathrm{~m}$ & $2.05 \mathrm{~m}$ & $2.05 \mathrm{~m}$ & $2.09 \mathrm{~m}$ & $2.14 \mathrm{~m}$ & $2.16 \mathrm{~d}(16.7)$ & $2.30 \mathrm{~m}$ & $1.36 \mathrm{~m}$ & $1.50 \mathrm{~m}$ & - & $1.48 \mathrm{~m}$ \\
\hline 7 & $5.40^{a}$ & $5.30 \mathrm{t}(6.0)$ & $5.32 \mathrm{t}(6.0)$ & $5.22 \mathrm{t}(6.9)$ & $5.08 \mathrm{brs}^{a}$ & $4.96^{a}$ & $5.08 \mathrm{brs}$ & $4.16 \mathrm{t}(7.1)$ & $3.93 \mathrm{t}(7.2)$ & $5.55 \mathrm{~d}(16.4)$ & $4.89 \mathrm{~m}$ \\
\hline 8 & - & - & - & - & - & - & - & - & - & - & - \\
\hline $9 \alpha$ & $2.05 \mathrm{~m}$ & $2.30 \mathrm{~m}$ & $\begin{array}{l}2.46 \mathrm{dd}(5.1, \\
12.9)\end{array}$ & $2.51^{a}$ & $2.17^{a}$ & $1.69 \mathrm{~s}$ & $2.10 \mathrm{~m}$ & $2.40^{a}$ & $2.32 \mathrm{~m}$ & $1.93 \mathrm{~m}$ & $\begin{array}{c}2.50 \mathrm{dd}(4.8, \\
14.6)\end{array}$ \\
\hline $9 \beta$ & $\begin{array}{c}2.81 \mathrm{dd}(5.6 \\
12.5)\end{array}$ & $\begin{array}{c}2.53 \mathrm{dd}(5.2 \\
12.8)\end{array}$ & $\begin{array}{c}2.52 \mathrm{dd}(5.1 \\
12.9)\end{array}$ & $2.51^{a}$ & $2.68^{a}$ & $2.79^{a}$ & $\begin{array}{c}2.75 \mathrm{dd}(5.2, \\
12.9)\end{array}$ & $\begin{array}{c}2.80 \mathrm{dd}(4.8, \\
14.9)\end{array}$ & $\begin{array}{c}2.80 \mathrm{dd}(4.9, \\
14.9)\end{array}$ & $\begin{array}{c}2.62 \mathrm{dd}(5.7 \\
12.8)\end{array}$ & $\begin{array}{c}2.77 \mathrm{dd}(4.8 \\
14.6)\end{array}$ \\
\hline 10 & $\begin{array}{c}5.02 \text { brs } W_{1 / 2}= \\
19.7\end{array}$ & $\begin{array}{c}5.05 \text { brs } W_{1 / 2}= \\
16.2\end{array}$ & $\begin{array}{c}5.08 \text { brs } W_{1 / 2}= \\
20.7\end{array}$ & $5.10 \mathrm{~m}$ & $\begin{array}{c}4.95 \text { brs } W_{1 / 2}= \\
18.8\end{array}$ & $4.93^{a}$ & $\begin{array}{c}4.98 \text { brs } W_{1 / 2}= \\
19.9\end{array}$ & $5.17 \mathrm{brs}^{a}$ & $\begin{array}{c}5.14 \text { brs } W_{1 / 2}= \\
19.8\end{array}$ & $\begin{array}{c}5.13 \text { brs } W_{1 / 2}= \\
18.0\end{array}$ & $5.10^{a}$ \\
\hline 11 & $6.98 \mathrm{~d}(1.8)$ & $6.83 \mathrm{~s}$ & $6.91 \mathrm{~s}$ & $6.87 \mathrm{~d}(1.5)$ & $7.27 \mathrm{~s}$ & $7.23 \mathrm{~d}(1.3)$ & $7.24 \mathrm{~d}(1.5)$ & $6.88 \mathrm{~s}$ & $6.90 \mathrm{~s}$ & $7.16 \mathrm{~s}$ & $6.93 \mathrm{~d}(1.6)$ \\
\hline 12 & - & - & - & - & - & - & - & - & - & - & - \\
\hline $13 \alpha$ & $2.15 \mathrm{~m}$ & $2.45 \mathrm{~m}$ & $2.45 \mathrm{~m}$ & $2.41 \mathrm{~m}$ & $2.55 \mathrm{~m}$ & $2.70 \mathrm{~m}$ & $2.55 \mathrm{~m}$ & $2.42^{a}$ & $2.40^{a}$ & $2.30^{a}$ & $2.39^{a}$ \\
\hline $13 \beta$ & $2.35 \mathrm{~m}$ & $2.35 \mathrm{~m}$ & $2.35 \mathrm{~m}$ & $2.36 \mathrm{~m}$ & $2.45 \mathrm{~m}$ & $2.34 \mathrm{~m}$ & $2.45 \mathrm{~m}$ & $2.40^{a}$ & $2.40^{a}$ & $2.30^{a}$ & $2.39^{a}$ \\
\hline $14 \alpha$ & $1.95 \mathrm{~m}$ & $2.15 \mathrm{~m}$ & $2.00 \mathrm{~m}$ & $2.11 \mathrm{~m}$ & $2.86 \mathrm{~m}$ & $2.92 \mathrm{td}(3.8,9.1)$ & $2.58^{a}$ & $2.05 \mathrm{~m}$ & $2.01 \mathrm{~m}$ & $2.05 \mathrm{~m}$ & $2.05^{a}$ \\
\hline $14 \beta$ & $1.50 \mathrm{~m}$ & $1.85 \mathrm{~m}$ & $1.85 \mathrm{~m}$ & $1.79 \mathrm{~m}$ & $2.67^{a}$ & $2.64 \mathrm{~s}$ & $2.58^{a}$ & $1.80 \mathrm{~m}$ & $1.82 \mathrm{~m}$ & $1.78 \mathrm{~m}$ & $1.78^{a}$ \\
\hline 15 & $1.62^{a}$ & $1.70 \mathrm{sp}(7.0)$ & $1.69 \mathrm{~m}$ & $1.67 \mathrm{sp} .(6.9)$ & - & - & $2.49^{a}$ & $1.70^{a}$ & $1.70^{a}$ & $1.64 \mathrm{sp}(6.8)$ & $1.71 \mathrm{sp}(6.9)$ \\
\hline \multirow[t]{2}{*}{16} & $0.91 \mathrm{~d}(6.6)$ & $0.91 \mathrm{~d}(7.0)$ & $0.91 \mathrm{~d}(7.0)$ & $0.90 \mathrm{~d}(6.9)$ & 5.02 brs & $4.96^{a}$ & $1.11 \mathrm{~d}(6.9)$ & $0.90 \mathrm{~d}(6.8)$ & $0.90 \mathrm{~d}(6.6)$ & $0.87 \mathrm{~d}(6.8)$ & $0.92 \mathrm{~d}(6.8)$ \\
\hline & & & & & $5.08^{a}$ & $4.96^{a}$ & & & & & \\
\hline 17 & $0.86 \mathrm{~d}(6.6)$ & $0.88 \mathrm{~d}(7.0)$ & $0.86 \mathrm{~d}(7.0)$ & $0.86 \mathrm{~d}(6.9)$ & $1.96 \mathrm{~s}$ & $1.88^{a}$ & $1.07 \mathrm{~d}(6.9)$ & $0.84 \mathrm{~d}(6.8)$ & $0.87 \mathrm{~d}(6.6)$ & $0.84 \mathrm{~d}(6.8)$ & $0.87 \mathrm{~d}(6.8)$ \\
\hline 18 & $1.25 \mathrm{~s}$ & $1.26 \mathrm{~s}$ & $1.30 \mathrm{~s}$ & $1.31 \mathrm{~s}$ & $1.79 \mathrm{~s}$ & $1.88^{a}$ & $1.67 \mathrm{~d}(1.2)$ & $1.36 \mathrm{~s}$ & $1.38 \mathrm{~s}$ & $1.37 \mathrm{~s}$ & $1.35 \mathrm{~s}$ \\
\hline \multirow[t]{2}{*}{19} & $1.63 \mathrm{~s}$ & $1.64 \mathrm{~s}$ & $1.58 \mathrm{~s}$ & $1.60 \mathrm{~s}$ & $1.58 \mathrm{~s}$ & $1.67 \mathrm{~s}$ & $1.59 \mathrm{~s}$ & $5.29 \mathrm{~s}$ & $5.19 \mathrm{~s}$ & $1.39 \mathrm{~s}$ & $5.28 \mathrm{~s}$ \\
\hline & & & & & & & & $5.20 \mathrm{~s}$ & $5.03 \mathrm{~s}$ & & $5.11 \mathrm{~s}$ \\
\hline $\mathrm{OCH}_{3}$ & $3.15 \mathrm{~s}$ & $3.13 \mathrm{~s}$ & & & & & $3.26 \mathrm{~s}$ & - & & & $2.03 \mathrm{~s}$ \\
\hline \multicolumn{12}{|l|}{ Ac } \\
\hline $\mathrm{OH}$ & & & & & & & & & & $8.60 \mathrm{br} \mathrm{s}$ & \\
\hline
\end{tabular}


Table 2. ${ }^{13} \mathrm{C}$ NMR Spectroscopic Data for Compounds 1-10 and 8a in $\mathrm{CDCl}_{3}$.

\begin{tabular}{|c|c|c|c|c|c|c|c|c|c|c|c|}
\hline Position & 1 & 2 & 3 & 4 & 5 & 6 & 7 & 8 & 9 & 10 & $8 \mathbf{a}$ \\
\hline 1 & $48.9 \mathrm{CH}$ & $76.7 \mathrm{C}$ & $76.7 \mathrm{C}$ & $77.0 \mathrm{C}$ & $142.9 \mathrm{C}$ & $143.3 \mathrm{C}$ & $147.3 \mathrm{C}$ & $77.0 \mathrm{C}$ & $77.0 \mathrm{C}$ & $76.8 \mathrm{C}$ & $77.0 \mathrm{C}$ \\
\hline 2 & $134.0 \mathrm{CH}$ & $130.0 \mathrm{CH}$ & $130.6 \mathrm{CH}$ & $131.9 \mathrm{CH}$ & $124.3 \mathrm{CH}$ & $124.2 \mathrm{CH}$ & $125.1 \mathrm{CH}$ & $131.5 \mathrm{CH}$ & $131.3 \mathrm{CH}$ & $131.8 \mathrm{CH}$ & $131.7 \mathrm{CH}$ \\
\hline 3 & $135.8 \mathrm{CH}$ & $134.2 \mathrm{CH}$ & $135.0 \mathrm{CH}$ & $135.8 \mathrm{CH}$ & $123.6 \mathrm{CH}$ & $123.4 \mathrm{CH}$ & $118.9 \mathrm{CH}$ & $135.9 \mathrm{CH}$ & $136.0 \mathrm{CH}$ & $135.5 \mathrm{CH}$ & $136.2 \mathrm{CH}$ \\
\hline 4 & $77.2 \mathrm{C}$ & $77.2 \mathrm{C}$ & $74.3 \mathrm{C}$ & $72.9 \mathrm{C}$ & $139.9 \mathrm{CH}$ & $141.5 \mathrm{C}$ & $134.4 \mathrm{C}$ & $72.6 \mathrm{C}$ & $72.6 \mathrm{C}$ & $72.4 \mathrm{C}$ & $72.9 \mathrm{C}$ \\
\hline 5 & $43.7 \mathrm{C}$ & $42.0 \mathrm{C}$ & $42.1 \mathrm{C}$ & $42.4 \mathrm{CH}_{2}$ & $40.3 \mathrm{CH}_{2}$ & $31.4 \mathrm{CH}_{2}$ & $86.0 \mathrm{C}$ & $38.6 \mathrm{CH}_{2}$ & $38.8 \mathrm{CH}_{2}$ & $45.2 \mathrm{CH}_{2}$ & $38.5 \mathrm{CH}_{2}$ \\
\hline 6 & $25.5 \mathrm{CH}_{2}$ & $21.8 \mathrm{CH}_{2}$ & $23.8 \mathrm{CH}_{2}$ & $23.2 \mathrm{CH}_{2}$ & $25.8 \mathrm{CH}_{2}$ & $26.6 \mathrm{CH}_{2}$ & $31.4 \mathrm{CH}_{2}$ & $25.1 \mathrm{CH}_{2}$ & $29.6 \mathrm{CH}_{2}$ & $127.4 \mathrm{CH}$ & $27.4 \mathrm{CH}_{2}$ \\
\hline 7 & $131.7 \mathrm{CH}$ & $131.7 \mathrm{CH}$ & $130.2 \mathrm{CH}$ & $131.8 \mathrm{CH}$ & $130.0 \mathrm{CH}$ & $129.6 \mathrm{CH}$ & $123.0 \mathrm{CH}$ & $89.8 \mathrm{CH}$ & $76.8 \mathrm{CH}$ & $134.8 \mathrm{CH}$ & $77.9 \mathrm{CH}$ \\
\hline 8 & $129.4 \mathrm{C}$ & $129.0 \mathrm{C}$ & $129.9 \mathrm{C}$ & $128.1 \mathrm{C}$ & $129.9 \mathrm{C}$ & $129.8 \mathrm{C}$ & $131.6 \mathrm{C}$ & $142.0 \mathrm{C}$ & $145.3 \mathrm{C}$ & $83.6 \mathrm{C}$ & $141.2 \mathrm{C}$ \\
\hline 9 & $44.8 \mathrm{CH}_{2}$ & $43.5 \mathrm{CH}_{2}$ & $42.7 \mathrm{CH}_{2}$ & $42.4 \mathrm{CH}_{2}$ & $44.5 \mathrm{CH}_{2}$ & $46.0 \mathrm{CH}_{2}$ & $44.7 \mathrm{CH}_{2}$ & $34.6 \mathrm{CH}_{2}$ & $34.0 \mathrm{CH}_{2}$ & $41.3 \mathrm{CH}_{2}$ & $36.3 \mathrm{CH}_{2}$ \\
\hline 10 & $80.3 \mathrm{CH}$ & $80.7 \mathrm{CH}$ & $80.9 \mathrm{CH}$ & $80.6 \mathrm{CH}$ & $79.8 \mathrm{CH}$ & $79.1 \mathrm{CH}$ & $80.0 \mathrm{CH}$ & $79.6 \mathrm{CH}$ & $79.8 \mathrm{CH}$ & $79.1 \mathrm{CH}$ & $79.4 \mathrm{CH}$ \\
\hline 11 & $149.6 \mathrm{CH}$ & $149.4 \mathrm{CH}$ & $148.8 \mathrm{CH}$ & $148.5 \mathrm{CH}$ & $149.3 \mathrm{CH}$ & $150.4 \mathrm{CH}$ & $149.3 \mathrm{CH}$ & $146.5 \mathrm{CH}$ & $147.0 \mathrm{CH}$ & $150.2 \mathrm{CH}$ & $145.8 \mathrm{CH}$ \\
\hline 12 & $133.5 \mathrm{C}$ & $134.2 \mathrm{C}$ & $135.0 \mathrm{C}$ & $135.3 \mathrm{C}$ & $133.9 \mathrm{C}$ & $131.6 \mathrm{C}$ & $133.7 \mathrm{C}$ & $135.9 \mathrm{C}$ & $135.3 \mathrm{C}$ & $133.1 \mathrm{C}$ & $136.3 \mathrm{C}$ \\
\hline 13 & $22.0 \mathrm{CH}_{2}$ & $22.0 \mathrm{CH}_{2}$ & $20.9 \mathrm{CH}_{2}$ & $21.3 \mathrm{CH}_{2}$ & $23.7 \mathrm{CH}_{2}$ & $23.7 \mathrm{CH}_{2}$ & $22.5 \mathrm{CH}_{2}$ & $20.7 \mathrm{CH}_{2}$ & $20.8 \mathrm{CH}_{2}$ & $20.2 \mathrm{CH}_{2}$ & $20.4 \mathrm{CH}_{2}$ \\
\hline 14 & $28.5 \mathrm{CH}_{2}$ & $33.7 \mathrm{CH}_{2}$ & $35.3 \mathrm{CH}_{2}$ & $33.7 \mathrm{CH}_{2}$ & $24.7 \mathrm{CH}_{2}$ & $23.3 \mathrm{CH}_{2}$ & $27.3 \mathrm{CH}_{2}$ & $34.6 \mathrm{CH}_{2}$ & $34.8 \mathrm{CH}_{2}$ & $35.0 \mathrm{CH}_{2}$ & $34.5 \mathrm{CH}_{2}$ \\
\hline 15 & $34.0 \mathrm{CH}$ & $39.4 \mathrm{CH}$ & $37.5 \mathrm{CH}$ & $38.9 \mathrm{CH}$ & $137.9 \mathrm{C}$ & $137.3 \mathrm{C}$ & $32.4 \mathrm{CH}$ & $38.8 \mathrm{CH}$ & $38.5 \mathrm{CH}$ & $38.9 \mathrm{CH}$ & $38.4 \mathrm{CH}$ \\
\hline 16 & $20.7 \mathrm{CH}_{3}$ & $17.8 \mathrm{CH}_{3}$ & $17.7 \mathrm{CH}_{3}$ & $17.1 \mathrm{CH}_{3}$ & $113.0 \mathrm{CH}_{2}$ & $113.4 \mathrm{CH}_{2}$ & $23.0 \mathrm{CH}_{3}$ & $17.7 \mathrm{CH}_{3}$ & $17.7 \mathrm{CH}_{3}$ & $17.8 \mathrm{CH}_{3}$ & $17.8 \mathrm{CH}_{3}$ \\
\hline 17 & $19.5 \mathrm{CH}_{3}$ & $16.9 \mathrm{CH}_{3}$ & $16.6 \mathrm{CH}_{3}$ & $17.5 \mathrm{CH}_{3}$ & $21.7 \mathrm{CH}_{3}$ & $21.6 \mathrm{CH}_{3}$ & $23.0 \mathrm{CH}_{3}$ & $16.8 \mathrm{CH}_{3}$ & $16.8 \mathrm{CH}_{3}$ & $16.8 \mathrm{CH}_{3}$ & $16.8 \mathrm{CH}_{3}$ \\
\hline 18 & $22.3 \mathrm{CH}_{3}$ & $23.0 \mathrm{CH}_{3}$ & $31.1 \mathrm{CH}_{3}$ & $28.8 \mathrm{CH}_{3}$ & $16.5 \mathrm{CH}_{3}$ & $24.0 \mathrm{CH}_{3}$ & $12.5 \mathrm{CH}_{3}$ & $29.9 \mathrm{CH}_{3}$ & $29.7 \mathrm{CH}_{3}$ & $29.5 \mathrm{CH}_{3}$ & $30.6 \mathrm{CH}_{3}$ \\
\hline 19 & $16.3 \mathrm{CH}_{3}$ & $17.1 \mathrm{CH}_{3}$ & $17.5 \mathrm{CH}_{3}$ & $17.9 \mathrm{CH}_{3}$ & $16.8 \mathrm{CH}_{3}$ & $16.1 \mathrm{CH}_{3}$ & $16.5 \mathrm{CH}_{3}$ & $118.4 \mathrm{CH}_{2}$ & $115.7 \mathrm{CH}_{2}$ & $25.8 \mathrm{CH}_{2}$ & $119.1 \mathrm{CH}_{2}$ \\
\hline 20 & $174.2 \mathrm{C}$ & $174.4 \mathrm{C}$ & $174.5 \mathrm{C}$ & $174.5 \mathrm{C}$ & $174.5 \mathrm{C}$ & $174.6 \mathrm{C}$ & $174.4 \mathrm{C}$ & $174.0 \mathrm{C}$ & $174.1 \mathrm{C}$ & $175.0 \mathrm{C}$ & $173.8 \mathrm{C}$ \\
\hline $\mathrm{OCH}_{3}$ & $50.4 \mathrm{CH}_{3}$ & $50.4 \mathrm{CH}_{3}$ & - & - & - & - & $56.5 \mathrm{CH}_{3}$ & - & - & - & - \\
\hline OAc & & & & & & & & & & & 21.4 \\
\hline$\overline{O A c}$ & & & & & & & & & & & 171.1 \\
\hline
\end{tabular}

